Abstracta Iranica Abstracta Iranica

Revue bibliographique pour le domaine irano-aryen

Volume 25 | 2004

Comptes rendus des publications de 2002

\title{
« Learning to Tax: The Political Economy of the Opium Trade in Iran, 1921-1941». Journal of Economic History 61, 2001, pp. 95-113.
}

\section{Rudi Matthee}

\section{OpenEdition}

1 Journals

\section{Édition électronique}

URL : http://journals.openedition.org/abstractairanica/4691

DOI : 10.4000/abstractairanica.4691

ISSN : 1961-960X

Éditeur :

CNRS (UMR 7528 Mondes iraniens et indiens), Éditions de l'IFRI

\section{Édition imprimée}

Date de publication : 15 mai 2004

ISSN : 0240-8910

Référence électronique

Rudi Matthee, « « Learning to Tax: The Political Economy of the Opium Trade in Iran, 1921-1941 ». Journal of Economic History 61, 2001, pp. 95-113. », Abstracta Iranica [En ligne], Volume 25 | 2004, document 187, mis en ligne le 15 mars 2006, consulté le 25 septembre 2020. URL : http://

journals.openedition.org/abstractairanica/4691; DOI : https://doi.org/10.4000/abstractairanica.4691

Ce document a été généré automatiquement le 25 septembre 2020.

Tous droits réservés 


\title{
« Learning to Tax: The Political Economy of the Opium Trade in Iran, 1921-1941 ». Journal of Economic History 61, 2001, pp. 95-113.
}

\author{
Rudi Matthee
}

1 The author of this article seeks to apply the theory of D. North to Iran's opium trade under Reza Shah. According to North, a ruler pursuing maximum wealth faces two constraints: a transaction-cost constraint and a political-competition constraint. Reza Shah's opium policy, it is argued, is a good example of a ruler discovering and responding to the constraints in his path. Intent on controlling and taxing the lucrative cash crop that opium had become since the late 19th century, Reza Shah quickly learned that he was in competition with an illegal market, that paying below-market prices for it would induce peasants to seek out the black market and that certain measures, such as the 1926 ban on the use of opium in public places, would drive this consumer into the private sphere and place it beyond the reach of government control and taxation. The article lacks any sense of the culturally specific and is based entirely on English-language sources, but nevertheless offers a revealing look at the dilemma its modernizing ruler faced in tapping an elusive source of revenue.

\section{INDEX}

Thèmes : 4.3. Histoire de l'Iran moderne (à partir de 1905) 
AUTEURS

RUDI MATTHEE

University of Delaware 